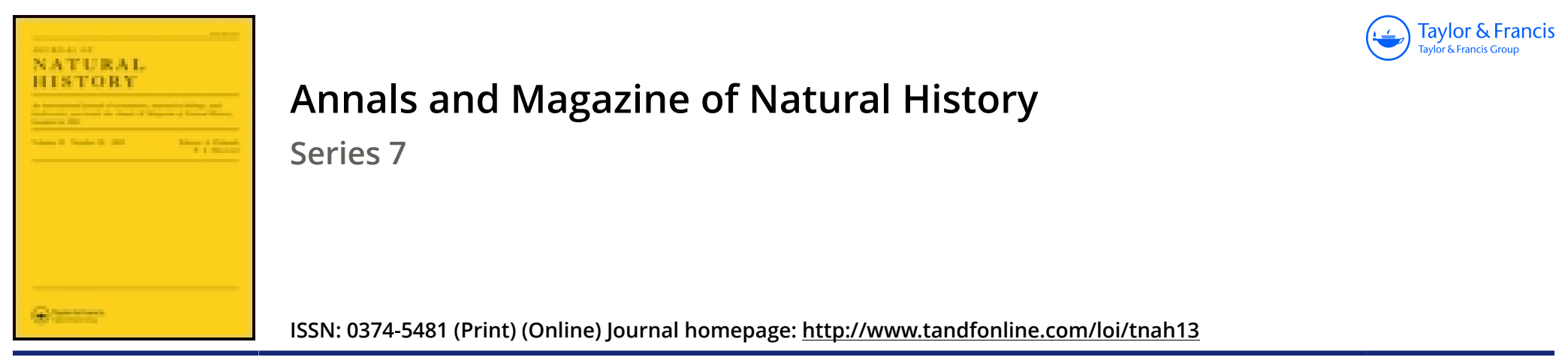

\title{
Echinocrinus versus Archœocidaris
}

\section{F.A. Bather}

To cite this article: F.A. Bather (1907) Echinocrinus versus Archœocidaris, Annals and Magazine of Natural History, 20:119, 452-456, DOI: 10.1080/00222930709487368

To link to this article: http://dx.doi.org/10.1080/00222930709487368

册Published online: 29 Sep 2009.

Submit your article to this journal $\pi$

Џll Article views: 2

Q View related articles $\asymp$

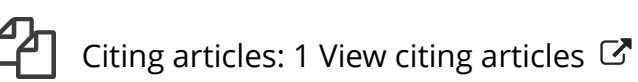




\title{
MISCELLANEOUS.
}

\author{
Echinocrinus versus Archcoocidaris. \\ By F. A. Bather, British Museum (Nat. Hist.).
}

A rove many preliminary studies for a memoir entitled "Triassic Echinoderms of Bakony" *, now passing through the press, I had to make up my mind on this long-vexed question. My friend Professor R. T. Jackson had to do the same for a forthcoming memoir on Palæozoic Echinoids, and on his asking my opinion I sent him the MS. of the present note. Had he not urged its publication, so as to clear the ground, I should have preferred to let someone else play this ungrateful rôle of nomenclatural chiffonier.

The name Eehinocrinus was proposed by Agassiz (1841, "Obs. sur les progrès récents de l'hist. nat. des Echinodermes," Monogr. d'Echinodermes, ii. p. 15) for Cidaris Urii Fleming, and Cidarites Nerei, Protei et priscus of Münster, and some unpublished species. The genus was thought by him to be a crinoid precursor of Echinoidea, possessing " la forme sphéroïdale des oursins avee des ambulacres étroits et de longs piquans épineux comme certains Cidaris," and " circonscrit dans les terrains de transition et dans les terrains houillers." On p. 20 Agassiz mentioned a new species of Echinocrinus sent to him by Austin.

According to modern rules and customs it is clear that the name Echinocrinus, unless preoccupied, which has never been maintained $\uparrow$, is perfectly valid, and that one of the four species mentioned by name must be taken as genotype.

T. \& T. Austin (1842, Ann. Nat. Hist. x. p. 111, Oct.) accepted the name Echinocrinus, and mentioned under it E. pomum, E. spinosus, $E$. anceps, and $E$. cidariformis? The last three were their own MS. species, while the first, ascribed to Agassiz, doubtless referred to the specimen above mentioned as sent by Austin to Agassiz, and was also still in MS. Consequently, except as showing that the name was accepted, this paper has no bearing on the interpretation of the genus.

The species $E$. spinosus and $E$. anceps were described by the Austins in March 1843 (Ann. Nat. Hist. xi. p. 207), but not in such a way as to permit of their recognition, while they did not state their horizon. The latter was compared with $E$. pomum, which, however, remained undescribed. Here occurs the first objection to the generic name: "It appears to us," they wrote, "that the name of our genus Sycocrinites and that of the Echinocrinus of Professor Agassiz require amendment, as their terminations imply affinities which do not exist." The meaning of this is not very clear, since by the title of their paper they still retained them under Crinoidea, and since by the words "Column unknown" they

* 'Resultate der wissenschaftl. Erforschung des Balatonsees,' i. Bd. 1 Th., Pal. Anh.

$\dagger$ Echinoencrinus, H. v. Meyer, 1826, is unfortunately similar, but it is far trom identical. 
implied that both genera were at any rate Pelmatozoa. Unpublished drawings by the Austins of some of their species of Sycocrinites have convinced me that those species were Crinoids after all. The criticism, therefore, was not at that time well founded.

In 1844 the name Echinocrinus was still maintained by no less a person than M'Coy ('Synops. Carb. Foss. Ireland'*, p. 173), who then gave a systematic diagnosis, recognizing the genus as an Fchinoid, and distinguishing it from Palcechinus on the one hand and Cidaris on the other. Under this name he proceeded to deseribe E. Munsterianus? (Kon.), E. glabrispina (Phill.), E. triserialis sp. n., E. Urii (Flem., incl. Cidaris benburbiensis Portlock), and E. vetustus (Phill.). Now, if by chance any objection were raised to Echinocrinus Agassiz, on the ground of insufficient or misleading description, and if the Austins' use of the name were ignored on similar grounds, the objector would still be compelled to accept the name as here confirmed by $\mathbf{M} \cdot \mathrm{Coy}$; and since all the species described by M'Coy were based on radioles only, with the exception of $E$. Urii, that species would naturally be selected as genotype, just as it would in the case of Agassiz' name $\uparrow$. So far the situation is unchanged. M'Coy, however, took the unfortunate step of mentioning that he "had long $\ddagger$ ago distinguished this species in " his "IISS. under the name of Archacocidlaris." Obviously this casual remark could not give any sanction to the name Archaocidaris, nor was it intended to do so. On the contrary, it is a question whether this mention did not put the name out of court at once and for ever as a mere homonym of Echinocrinus $\S$.

Once these fossils were clearly understood to be Echinoids and unrelated to Crinoids the obvious appropriateness of $\mathrm{M}^{\prime} \mathrm{Coy}^{\prime} \mathrm{s}$ MS. name led to its adoption by some authors. Thus, in 1845, Murchison, Verneuil, and Keyserling ('Geol. Russia,' ii. pp. xiv \& 396), in assigning Cidaris rossicus Buch, to the newly established genus, asserted their preference for the name Archoocidaris. Nowhere in the volume, however, is this species called anything but Cidaris (or Cidarites) rossicus. It would, therefore, scarcely be possible to regard the name Archcoocidaris as given any standing by those authors; nor, if occasion arose, could it be restricted on these grounds to any genus that might be established with $C$. rossicus as

* I am aware that, strictly speaking, this work was first published in 1862 by Messrs. Williams and Norgate; but many copies were privately distributed by Sir Richard Griffith towards the close of 1844 and subsequently. Desor, however, had not yet seen it in 1857 .

$\dagger$ If anyone were to insist on the first species mentioned being taken as the genotype, he would select $E$. Urii if he accepted Agassiz, but E. glabrispina if he accepted only $\mathrm{H}^{\circ} \mathrm{Coy}$. $E$. Munsterianus being marked with a ? could not be selected.

$\ddagger$ None the less in 1842 he called this species merely Cidaris Urii. See R. [J.] Griffith, " Notice respecting the Fossils of the Mountain Limestone of Ireland \&c.' p. 12 : printed Dublin, 1842.

$\S$ In the legend to the lithographed plates the name Archaocidaris, which had been printed, was erased, and the name Echinocrinus inserted by hand. 
genotype. Admittedly the name remains a pure homonym of Echinocrinus.

That the view just expressed was the one at that time adopted by a man of sane judgment is proved by Bronn's "Index Palæontologicus" ('Nomenclator,' p. 443; 1848), where Echinocrinus is definitely accepted with Archceocidaris as a synonym. To this genus Bronn refers all the species hitherto mentioned, except MS. names and except $E$. triserialis M'Coy, while he adds Cidaris deucalionis Eichw. as a possible synonym of $E$. rossicus.

In November 1846, however, Desor, in Agassiz \& Desor ("Cat. raisonnée des Ech.," Ann. Soi. Nat. (3) vi. p. 340) founded the genus Palceocidaris for the Cidaris Nerei, Protei, and prisca of Münster, previously placed by Agassiz in Echinocrinus. That the intention was simply to supplant the name Echinocrinus by one more appropriate to the echinoid nature of the fossils, appears from a note in Desor's 'Synopsis' (p. 154), as well as from the omission of Echinocrinus from the 'Catalogue.' Since, however, no such statement was made at the time, it might be possible to assign to Echinocrinus the genotype Cidaris Urii, and to Palceocidaris the genotype Cidaris Nerei, and ultimately, should subdivision of genera proceed on these lines, to use both names. Down to this present, however, no writer has doubted that $C$. Nerei and $C$. Urii are congeneric, and Palceocidaris must therefore be regarded as either a homonym or a synonym of Echinocrinus.

The name Palceocidaris was no doubt proposed in ignorance of M'Coy's name Archoocidaris, and M'Coy (1849, Ann. Nat. Hist. (2) iii. p. 252) rightly pointed out that, if Echinocrinus were to give place on any grounds to a later name, then Archoecidaris was prior to Palceocidaris; and this view was accepted by Desor (1857, 'Synopsis,' p. 154). M'Coy's reasons for reversing his own previous action were thus expressed:-(1) "Agassiz neither indicated the affinities nor gave any descriptive notice of the genus Echinocrinus, while I have done both for my Archoeocidaris." (2) "Several of the continental geologists have not followed my example in rejecting my own name, but prefer Archoocidaris." (3) Agassiz and Desor, as above mentioned, have given up Agassiz' own name. Of these reasons the only one that could have any validity is the first; but the statement is not entirely correct, since Agassiz did indicate what, in his opinion, were the affinities of Echinocrinus, and he did give a descriptive notice two lines long. The incorrectness of his opinion and the insufficiency of his notice were fully compensated for by his mention of four well-known species. No contemporary worker failed to understand precisely what Agassiz meant by Echinocrinus. That the name accords ill with present knowledge may be admitted, but it is no more misleading than M'Coy's own name Codaster, proposed in the very same paper for a fossil "obviously allied to Pentremites," or than Agelacrinus for an Edrioasteroid, or Phrissocystis for an Echinoid. As for the "several continental geologists" of M'Coy's paragraph (2), I have been unable to discover them; but it may be added that d'Orbigny 
(1850, 'Prodrome,' i. p. 154) adopted Echinocrinus with Palceocidaris as a synonym, and left Archoocidaris out of consideration, presumably as a mere MS. name.

Thus far, then, the result of our examination is to reinstate Echinocrinus Agassiz, with Archoocidaris as a pure homonym and Paloocidaris as a syuonym. The name Archæocidaridæ will also have to go. There remain for consideration various attempts at subdividing the original genus Echinocrinus, or the relegation of certain species to other genera.

Desor (1857, 'Synopsis,' p. 155) distinguished a new genus Eocidaris from Archoocidaris (i. e. Echinocrinus) on the ground that the primary tubercles of the interambulacrals were devoid of a halo ("second anneau"), and he included in this genus, inter alia, E. Verneuilana (King), E. rossica (Buch), and E. Munsteriana (Kon.), all species which had at one time been referred to Echinocrinus or Archooocidaris.

To the interpretation of Eocidaris I shall ask permission to recur in a subsequent note, and confine myself here to pointing out that the result of Desor's action at any rate was to restrict Echinocrinus to species with primary interambulacral tubercles perforate, noncrenelate, scrobiculate, and, above all, annulate (i. e. with a "basal terrace").

The next step appears to have been that taken by Meek and Worthen (1869, Proc. Acad. Nat. Sci. Philadelphia), who, after describing Eocidaris ? squamosa (p. 79), showed its distinction from Archaocidaris and Eocidaris, and tentatively proposed the name Lepidocidaris (p. 81). This resembles Eocidaris in the absence of a basal terrace from the interambulacral primary tubercles, but is presumed to differ from it in the presence of eight columns of interambulacrals at the ambitus and demiplates alternating with primary ambulacrals. The structure of these parts in Eocidaris is still unknown; but the genus Lepidocidaris has been generally accepted (see Jackson, 1896, p. 220; and Tornquist, 1897, pp. 51=773).

In 1883 Pomel ('Class. Méth.' p. 113) erected the genus Cidarotropus, with genotype Archoocidaris Wortheni Hall. Pomel drew no distinction between the interambulacral plates, but based the genus on the two series of regular primary ambulacrals, each with two pores in the middle of it. Our knowledge of these structures in the original species of Echinocrinus is not enough to warrant a distinction on these grounds.

Tornquist, howerer $\left(1897^{*}\right.$, pp. $\left.52=774\right)$, has divided the species into two main groups. That including the genotype $E$. Urii, together with $E$. Nerei, $E$. Wervekei, and $E$. Grueneri, possesses interambulacrals with a clear basal terrace from which thick wedgeshaped ridges radiate to the margin of the plate. The other group, which includes E. rossicus, E. Trautscholdi, E. Wortheni, E. biangulatus, $E$. megastylus, and $E$. Norwoodi, has interambulacrals with a basal terrace well developed on some, but sometimes entirely absent

* “Das fossilfuihrende Untercarbon \&c.," Abh. geol. Karte Elsass, v. 
from others, with smooth scrobicule around which are numerous small serobicnlar tubercles in one or more circles; these tubercles are usually especially numerous on the adoral and adapical margins, particularly the latter, where they form many close-serried rows.

E. Munsterianus is, according to Tornquist, the representative of yet a third group, the characters of which he does not gire. Does he know more of it than the radioles?

Tornquist has given no generic or subgencric names to the groups defned by him, but Lambert (1900*, p. 42), while retaining for the first group the name Echinocrinus (in accordance with the views above expressed), has suggested the resuscitation of Archoocidaris for the second group. This, of course, is quite inadmissible, as already explained (p. 453). If a name be required, "Cidarotropus" is ready to hand, with genotype C. Wortheni. But it is really too early to make this division. Unfortunately so many species have been based on radioles or on isolated interambulacral plates that they cannot be referred with any security to either of these groups. Perhaps we may be allowed to retain the word "Archæocidaris" as a convenient appellation for such doubtful cases, much as the word "Ammonites" still has its uses.

The following statement summarizes the conclusions with regard to the principal generic names mentioned in this study:-

Echinochinus Agassiz, 1841.

Genotype Cidaris Urii Fleming.

Syn. Archeocidaris, M'Coy, MS., 1844.

Palcoocidaris, Desor, 1846.

Archaocidaris, M'Coy, 1849.

Cidarotropus Pomel, 1883.

Genotype Archoocidaris Wortheni Hall.

Syn. Eocidaris Desor (pars), 1857.

Archcoocidaris Lambert (non M'Coy), 1900.

Lepinocidaris Meek \& Worthen, 1869, em. Jackson, 1896.

Genotype Eocidaris? squamosa Meek \& Worthen, 1869.

Of these genera, Echinocrinus and Lepidocidaris are well established, but Cidarotropus rests, for the present at any rate, on an insecure basis, and, if not accepted, must with its synonyms be added to the list of synonyms of Echinocrinus.

The choice of a name to replace Archæocidaridø is therefore limited to two. Echinocrinidæ, the natural successor, does not suggest the systematic position of the Family so well as LeridoCIDARID $A$, and I therefore propose to use the latter.

* "Ettude sur quelques Échin, de l'Infra-Lias \&c." Bull. Soc. Sci. Yonne, liii. 1er semestre, pt. 2. 